Terbit online pada laman web jurnal : http://jurnal.iaii.or.id

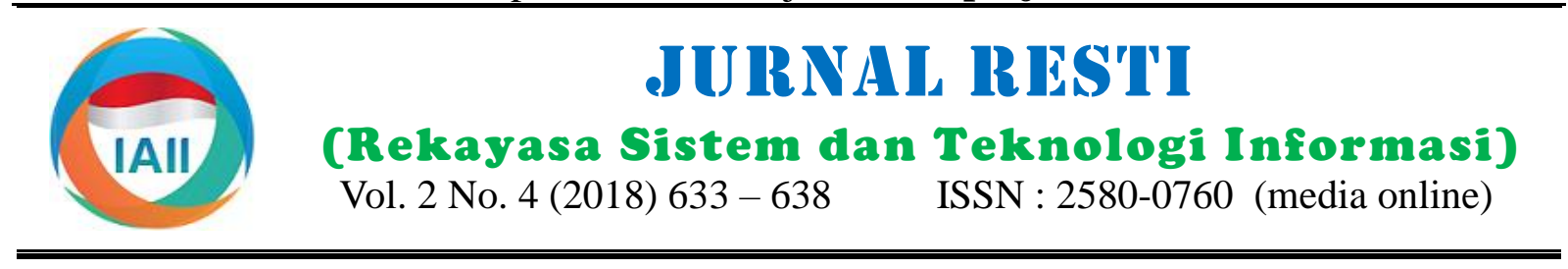

\title{
Deteksi Bot Spammer Pada Twitter Menggunakan Smith Waterman Similarity Dan Time Interval Entropy
}

\author{
Imam Safi'i $^{\mathrm{a}}$, Arief Setyanto ${ }^{\mathrm{b}}$, Suwanto Raharjo $^{\mathrm{c}}$ \\ ${ }^{a}$ Magister Teknik Informatika, Universitas Amikom Yogyakarta, nangimam75@gmail.com \\ bMagister Teknik Informatika, Universitas Amikom Yogyakarta, arief_s@amikom.ac.id \\ ${ }^{\mathrm{c}}$ Teknik Informatika, Fakultas Teknologi Industri, Institut Sains \& Teknologi AKPRIND Yogyakarta, wa2n@akprind.ac.id
}

\begin{abstract}
Twitter is a social media that interacts through 140-character text-based tweet posts including photos, videos and hyperlinks. Spam tweets contain harmful messages sent continuously. Besides disturbing it is also dangerous for the recipient, exacerbated by the use of bots that automatically and quickly spread spam messages that can cause data damage. This study aims to detect spam bots by utilizing the similarity of tweets using Smith Waterman and the posting time interval. Data tweets are collected using scrap libraries in python in the form of id, text, time, link, based on datasets labeled as available. The data is carried out by text preprocessing steps to clean the text and then do the calculations. The calculation results of both the similarity method and the post time interval are then classified with $k$-Neaset Neighbor with the previous dataset that has been labeled to get the spam or legitimate bot prediction results. The results of classification experiments with several combinations of $k$ to detect spam bots with similarity criteria and entropy interval obtained the best results $k=3$ Neirest Neighbor and 10 fold Cross Validation with a predictive value of detection accuracy of $80 \%, 84 \%$ precission and $84 \%$ recall.
\end{abstract}

Keywords: Detect spam bots on Twitter, with waterman similarity and time interval entropy, $k$-NN classification for spammer predictions

\begin{abstract}
Abstrak
Twitter merupakan media sosial yang berinteraksi melalui postingan tweet yang berbasis teks 140 karakter termasuk foto, video dan hyperlink. Tweet spam berisi pesan membahayakan yang dikirim secara terus-menerus. Selain mengganggu juga membahayakan bagi yang menerima, diperburuk dengan penggunaan bot yang secara otomatis dan cepat menyebarkan pesan spam yang dapat menyebabkan kerusakan data. Penelitian ini bertujuan mendeteksi bot spam dengan memanfaatkan kemiripan tweets menggunakan Smith Waterman dan Interval waktu posting. Data tweets dikumpulkan menggunakan library scrap di python berupa id, text, time, link, berdasarkan dataset berlabel yang telah tersedia. Data tersebut dilakukan tahapan text preprocessing untuk membersihkan teks kemudian dilakukan perhitungan. Hasil perhitungan dari kedua metode similarity dan interval waktu posting kemudian diklasifikasi dengan $k$-Neaset Neighbour dengan dataset sebelumnya yang telah berlabel untuk mendapatkan hasil prediksi bot spam atau legitimate. Hasil percobaan klasifikasi dengan beberapa kombinasi $k$ untuk mendeteksi bot spam dengan kriteria similarity dan interval entropy diperoleh hasil terbaik $k=3$ Neirest Neighbour dan 10 fold Cross Validation dengan nilai prediksi deteksi accuracy sebesar 80\%, precission $84 \%$ dan recall $84 \%$.
\end{abstract}

Kata kunci : Deteksi bot spam di twitter, smith waterman similarity dan time interval entropy, klasifikasi k-NN untuk prediksi spammer

(C) 2018 Jurnal RESTI

\section{Pendahuluan}

Masyarakat Indonesia merupakan pengguna terbesar ke 5 setelah USA, Brazil, Jepang dan Inggris, pada penggunaan platform media sosial twitter[1]. Twitter dengan pengguna lebih dari 500 juta dan 400 juta tweet perharinya, memungkinkan pengguna untuk berbagi pesan[1]. Pengguna Twitter menulis tentang berbagai opini, isu-isu yang sedang terjadi atau berbagi suatu produk menyebabkan para spammer mulai menyebarkan sejumlah besar pesan spam dengan tujuan spammer berbahaya bagi pengguna media sosial, tidak komersialnya[2]. Tweet spam berisi pesan singkat atau link yang dikirimkan secara terus-menerus dan mengganggu pengguna yang menerima. Karakteristik tweet spam yaitu seringkali di posting secara otomatis dan teratur dalam waktu yang dekat dan tweet spam seringkali tidak memiliki ungkapan/ekspresi berbeda dengan pengguna asli yang mem-posting tweet yang memiliki ungkapan ekspresi. Tweet spam di perburuk dengan penggunaan program otomatis (bot)[3]. Bot

Diterima Redaksi : 17-08-2017 | Selesai Revisi : 01-10-2017 | Diterbitkan Online : 02-11-2017 
hanya berpotensi merusak tweet, juga dapat matriks yang berisi semua kemungkinan kesamaan, menyebabkan kerusakan data[4]. Twitter memiliki membandingkan nilai-nilai dari sub matriks hingga mekanisme untuk penanganan bot spammer dengan didapatkan nilai yang optimal[9][10]. Implementasi melaporkan, namun memiliki kelemahan apabila algoritma Smith Waterman dan Cosine Similarity untuk laporan pengguna Twitter yang dikumpulkan ternyata menghitung kemiripan teks berdasarkan urutan dan laporan palsu[5].

kemunculan kata[11]. Preprocessing merupakan Penelitian yang akan dilakukan dalam deteksi bot spam pengubahan bentuk text yang terstruktur secara acak ini menggunakan parameter tweets similarity dengan menjadi terstruktur sesuai kebutuhan, Preprocessing Smith Waterman karena belum ada yang menggunakan terdiri dari case folding, tokenizing, removing metode ini untuk deteksi kemiripan tweets. Adapun punctuation, removing stop words, removing Link/URL, penelitan yang terdahulu menggunakan cosine dan stemming. similarity untuk kemiripan tweets dan membuang url didalam tweets[6]. Penelitan ini akan memanfaatkan 3. Metodologi Penelitian URL pada tweets sebagai parameter dan metode similarity lain dalam deteksi bot. Selain kemiripan Penelitian ini menggunakan metode eksperimen tweets peneliti memanfaatkan interval waktu posting dimana peneliti mengkaji kemampuan Natural tweets menggunakan interval entropy. Hasil Language Processing dalam melakukan deteksi perhitungan dari kedua metode tersebut kemudian terhadap akun spam, sehingga dapat dikategorikan diklasifikasi dengan metode k-Nearest Neighbour sebagai penelitian inovasi. Dataset yang digunakan untuk memprediksi akun bot spam atau legitimate berasal dari Trend Micro's Web Reputation Technology dengan dataset yang telah berlabel. Hasil klasifikasi di telah berlabel spam dan legitimate, kemudian validasi dengan $k$-fold cross validation untuk dikumpulkan kembali sebanyak 2000 Tweets dengan mendapatkan nilai accuracy, precission dan recall.

Penelitian ini bertujuan untuk menunjukkan hasil pemrosesan text standar.

proporsi akun bot spam atau legitimate user pada

twitter menggunakan pendekatan Tweets similarity 3.1 Pengumpulan Data

dan time interval antar tweets. Performa klasfikasi k-

NN untuk memprediksi akun bot spam atau legitimate dengan menggabungkan metode Smith Waterman dan Time Interval Entropy.

\section{Tinjauan Pustaka}

Deteksi antara bot spammer dan legitimate user menggunakan kombinasi metode kemiripan dengan cosine similarity dan waktu antar posting tweet, untuk url didalam tweets tidak digunakan, penelitian tersebut mendapatkan tingkat accuracy $85 \%$, precission $94 \%$ dan recall $90 \%[7]$. Dimana time stamp digunakan untuk menghitung interval antar tweet dan kemiripan tweet menggunakan unigram matching-based. Data tweet yang digunakan terdiri atas kumpulan akun normal dan akun yang terindikasi sebagai bot spammer yang sudah di kategorikan sebelumnya yang dihasilkan dari penelitianya lebih baik daripada penelitian yang menggunakan satu metode. Dalam penelitianya ada beberapa parameter seperti $U R L$ yang dibuang saat preprocessing, penelitian[6] menggunakan URL sebagai salah satu parameter untuk deteksi spam campaigns. Penelitian deteksi bot spammer dengan memanfaatkan fitur waktu dilakukan[8] fitur waktu posting dalam penelitian ini belum bisa mengidentifikasi tweet yang dilakukan berulang kali oleh legitimate user, sehingga legitimate dapat terinditifikasi sebagai spammer. Smith Waterman merupakan algoritma yang digunakan untuk menghitung kemiripan dua buah teks atau dokumen berdasarkan urutan. Algoritma ini mempunyai efek yang baik dalam pencocokan, menggunakan sub

Peneliti menggunakan dataset yang telah disediakan sebanyak 40 akun, dan masing-masing akun diambil 50 Tweets dengan proses scrapping, kemudian peneliti membagi menjadi dua data, yaitu data spammer sebanyak 25 akun dan data legitimate sebanyak 15 akun, terkumpul 2000 tweets dari keseluruhan akun kemudian dilakukan pemrosesan teks standar Tweets.

\subsection{Analisis Data}

Data tweets dilakukan standard text preprocessing untuk membersihkan teks agar meningkatkan akurasi dalam deteksi spammer dan legitimate.

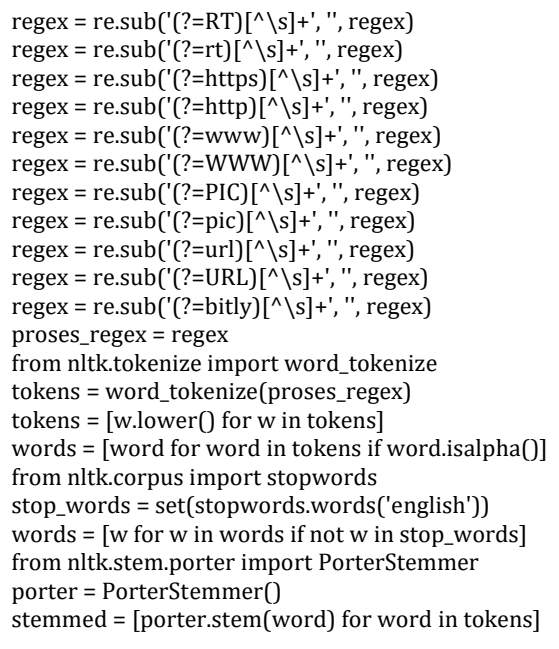

Gambar 1. Preprocessing Data Tweets 
Tahapan analisis data dengan standart text processing Dua urutan urutan kueri dan urutan basis data akan dengan bahasa python dan library dari nltk sebagai dibandingkan, didefinisikan sebagai $\mathrm{A}=a_{1} a_{2} \ldots a_{n}$ dan berikut :

a. Masukan Tweets asli dari setiap Tweets yang $\mathrm{B}=b_{1} b_{2} \ldots b_{n}$ jadilah urutan yang harus disesuaikan, dimana $\mathrm{n}$ dan $\mathrm{m}$ adalah panjang dari masing-masing $\mathrm{A}$ dan B.

diproses seringkali bersifat noisy karena berupa URL atau HTML link, simbol, kode angka ASCII, tanda baca selain koma, titik, tanda seru dan tanda tanya, singkatan kata tidak baku, dan kata dalam bahasa asing. Pada penelitian ini, bahasa asing yang ditemukan tidak memiliki arti karena berfokus pada bahasa Inggris saja.

b. Tahapan menghilangkan url, www, http/s, pic, bitly, Simbol (\#,RT,@), kode angka ASCII, dan Tanda Baca koma, titik, tanda seru, dan tanda tanya, kemudian Lower Case Folding melalui proses ini dari library nltk;

1. Tentukan matriks substitusi dan skema penalti gap

a. $s(a, b)$ Nilai kesamaan elemen yang merupakan dua urutan

b. $W_{k}$ hukum dari celah yang memiliki panjang $k$ 2. Buatlah matriks penilaian $H$ dan inisialisasi baris pertama dan kolom pertama. Ukuran dari matriks penilaian adalah $(\mathrm{n}+1) *(\mathrm{~m}+1)$. Perhatikan pengindeksan berbasis 0

$$
H_{k 0}=H_{0 l}=0 \text { for } 0 \leq k \leq n \text { and } 0 \leq 1 \leq m
$$

\subsection{Time Interval Entropy}

c. Tokenizing tahapan pemotongan berupa kata untuk Time interval entropy digunakan untuk menangkap setiap kalimat yang ada kemudian dipisahkan pola keteraturan waktu posting tweets yang menjadi kata token dengan cara mendeteksi spasi menunjukkan otomatisasi, TIE $(\mathrm{H})$ dihitung dengan yang ditemukan.

menggunakan persamaan (1) dan persamaan (2).

d. Stop Words Removal menghilangkan kata umum yang tidak memiliki pengaruh signifikan pada sebuah kalimat. Hal ini diselesaikan dengan melakukan proses import daftar stop word dari library nltk.

e. Stemming masukan teks yang sudah dipisahkan menjadi kata token kemudian akan mudah untuk diproses. Salah satunya adalah stemming yang berusaha mengembalikan setiap kata yang ditemukan kembali ke dalam bentuk baku.

\subsection{Similarity Smith Waterman}

Algoritma Smith Waterman merupakan algoritma klasik yang telah dikenal luas dalam bidang bioinformatika sebagai metode yang dapat mengidentifikasi local similarities (penyejajaran sequence) yaitu proses penyusunan dua local sequences (rangkaian/susunan atau rentetan) protein sequences sehingga kemiripan antara dua sequence tersebut akan terlihat. Berdasarkan fungsi proses penyejajaran sekuens tersebut, maka algoritma ini dapat digunakan dalam proses pendeteksian kemiripan tweets dari yang dianggap sebagai tweets spammer dengan cara melihat kemiripan antar tweets yang dipostingkan. Algoritma Smith Waterman sendiri banyak digunakan untuk menghitung penyelarasan lokal yang optimal[12][13].

$$
\begin{gathered}
A b c b a d b c a \\
|||||||| \mid \\
A b-b-d b d a
\end{gathered}
$$

$$
\begin{aligned}
& H_{\Delta T}(T i)=-\sum_{i=1}^{n T} P \Delta T\left(\Delta t_{i}\right) \log \left(P \Delta T\left(\Delta t_{i}\right)\right) \\
& P \Delta T\left(\Delta t_{i}\right)=\frac{n \Delta t_{i}}{\sum_{k=1}^{n T} n \Delta t_{k}}
\end{aligned}
$$

Dimana $\Delta T$ merepresentasikan interval waktu antar tweets, dimana $P \Delta T\left(\Delta t_{i}\right)$ menunjukkan probabilitas interval waktu $\Delta T_{i}$. Komponen entropy dapat mendeteksi waktu periodik yang merupakan indikasi kuat terjadinya otomatisasi. Penggunaan Twitter yang memiliki entropy lebih rendah dari threshold akan diklasifikasikan sebagai bot spammer karena nilai entropy rendah dibawah threshold menunjukkan perilaku yang teratur[2].

\subsection{K-Nearest Neighbour}

Klasifikasi $k$-Nearest Neighbour mencari sejumlah $k$ objek data atau pola (dari semua pola latih yang ada) yang paling dekat dengan pola masukan, kemudian memilih kelas dengan sejumlah pola terbanyak diantara $k$ pola tersebut. Penentuan $k$ pola terdekat dilakukan berdasarkan ukuran jarak, similarity atau dissimilarity, bergantung jenis atributnya. Pada proses pengklasifikasian, algoritma k-Neirest Neighbour menggunakan keterangan sebagai nilai prediksi dari sampel uji yang baru, Jarak yang digunakan adalah jarak Euclidean Distance. Klasifikasi dua kelas menggunakan $k$-Nearest Neighbour, adapaun tahapan algoritma ini adalah:

Gambar 2. Optimal alignment dua substring 


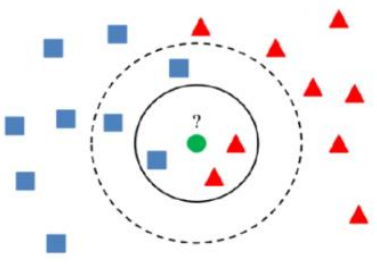

Gambar 3. Klasifikasi K-Nearest Neighbour

1. Untuk setiap pola latih $\langle x, f(x)\rangle$, tambahkan pola tersebut ke dalam daftar pola latih

2. Untuk sebuah pola masukan $\mathrm{x}_{\mathrm{q}}$

a. Misalkan $\mathrm{x}_{1}, \mathrm{x}_{2} \ldots, \mathrm{x}_{\mathrm{k}}$ adalah $k$ pola yang memiliki jarak terdekat (tetangga) dengan $x_{\mathrm{q}}$

b. Kembalikan kelas yang memiliki jumlah pola paling banyak diantara $k$ pola tersebut sebagai kelas keputusan.

\subsection{K-Fold Cross Validation}

Pada penelitian ini data berjumlah 40 user kemudian dibagi menjadi data training dan testing dengan perbandingan 80:20. K-Fold Cross Validation pada penelitian ini ditentukan jumlah fold 10, untuk memperkirakan tingkat kesalahan yang terjadi, sebab data training pada setiap fold cukup berbeda dengan data training yang asli.

\subsection{Alur Penelitian}

Tahapan penelitian yang dilakukan dalam deteksi bot spammer dan legitimate.

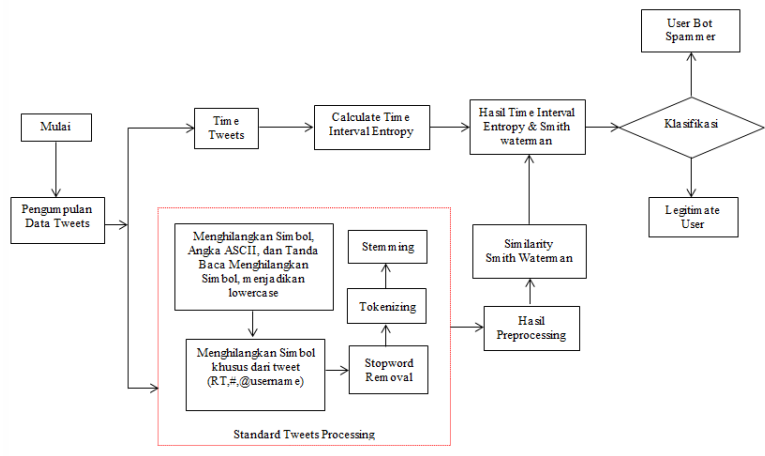

Gambar 4. Alur Penelitian

\section{Hasil dan Pembahasan}

Dari beberapa hasil percobaan yang telah dilakukan dengan menentukan jumlah tetangga 1 sampai 5 pada klasifikasi dengan metode Nearest Neighbour maka peneliti mengambil kesimpulan bahwa $k=3$ memiliki accuracy deteksi lebih tinggi. Peneliti menggunakan validasi dari beberapa percobaan klasifikasi dengan $K$ Fold Cross Validation sebanyak 10 dan 5 fold. Hasil percobaan tersebut menghasilkan tingkat accuracy pada $k=5$ dan 10 fold sebesar $78 \%$. Percobaan $k=5$ dan 5 fold mendapatkan tingkat accuracy sebesar $73 \%$.
Percobaan $k=4$ dan 10 fold mendapatkan tingkat accuracy sebesar 78\%. Percobaan $k=4$ dan 5 fold mendapatkan tingkat accuracy sebesar $73 \%$. Percobaan $k=3$ dan 10 fold mendapatkan tingkat accuracy sebesar $80 \%$. Percobaan $k=3$ dan 5 fold mendapatkan tingkat accuracy sebesar $75 \%$. Percobaan $k=2$ dan 10 fold mendapatkan tingkat accuracy sebesar 70\%. Percobaan $k=2$ dan 5 fold mendapatkan tingkat accuracy sebesar $73 \%$. Percobaan $k=1$ dan 10 fold mendapatkan tingkat accuracy sebesar 70\%. Percobaan $k=1$ dan 5 fold mendapatkan tingkat accuracy sebesar $73 \%$.

Dari beberapa percobaan kombinasi $k$ tetangga pada Nearest Neighbour dan Fold Cross Validation dapat diketahuin $k=3$ dan 10 fold mendapatkan nilai accuracy $80 \%$ lebih besar pada deteksi bot spammer dengan parameter similarity tweets dan interval entropy antar posting.

\subsection{Hasil Klasifikasi}

Deteksi bot spammer dengan dengan parameter similarity dan time interval entropy dengan tetangga terdekat sebesar $k=3$ Nearest Neighbour dan 10 Fold Cross Validation menghasilkan prediksi

Tabel 1. Hasil k=3 Nearest Neighbour dan 10 Fold Cross Validation

\begin{tabular}{|c|c|c|c|c|}
\hline $\begin{array}{l}\text { User } \\
\text { Id }\end{array}$ & $\begin{array}{c}\text { Tweets } \\
\text { Similarity }\end{array}$ & $\begin{array}{c}\text { TIE } \\
\text { Tweets }\end{array}$ & $\begin{array}{c}\text { Label } \\
\text { Asli }\end{array}$ & $\begin{array}{c}\text { Label } \\
\text { Klasifikasi }\end{array}$ \\
\hline 1 & 62 & 1.69 & Spam & Spam \\
\hline 2 & 34 & 1.05 & Spam & Spam \\
\hline 3 & 16 & 1.65 & Spam & Spam \\
\hline 4 & 21 & 1.67 & Human & Spam \\
\hline 5 & 34 & 1.69 & Spam & Spam \\
\hline 6 & 23 & 1.67 & Spam & Human \\
\hline 7 & 11 & 1.68 & Human & Human \\
\hline 8 & 0 & 1.69 & Human & Human \\
\hline 9 & 76 & 1.69 & Spam & Spam \\
\hline 10 & 42 & 1.37 & Spam & Spam \\
\hline 11 & 7 & 1.69 & Human & Human \\
\hline 12 & 14 & 1.68 & Human & Human \\
\hline 13 & 17 & 1.67 & Spam & Spam \\
\hline 14 & 78 & 1.66 & Spam & Spam \\
\hline 15 & 0 & 1.68 & Human & Human \\
\hline 16 & 25 & 1.69 & Human & Spam \\
\hline 17 & 15 & 1.67 & Spam & Human \\
\hline 18 & 75 & 1.54 & Spam & Spam \\
\hline 19 & 10 & 1.69 & Human & Human \\
\hline 20 & 37 & 1.69 & Human & Spam \\
\hline 21 & 29 & 1.69 & Spam & Spam \\
\hline 22 & 26 & 1.68 & Spam & Spam \\
\hline 23 & 14 & 1.69 & Human & Human \\
\hline 24 & 28 & 1.68 & Human & Spam \\
\hline 25 & 20 & 1.69 & Spam & Spam \\
\hline 26 & 80 & 1.67 & Spam & Spam \\
\hline 27 & 43 & 1.4 & Spam & Spam \\
\hline 28 & 6 & 1.69 & Human & Human \\
\hline 29 & 36 & 1.49 & Spam & Spam \\
\hline 30 & 51 & 1.69 & Spam & Spam \\
\hline 31 & 30 & 1.28 & Spam & Spam \\
\hline 32 & 14 & 1.69 & Human & Human \\
\hline 33 & 65 & 1.68 & Spam & Spam \\
\hline 34 & 14 & 1.61 & Spam & Human \\
\hline 35 & 69 & 1.53 & Spam & Spam \\
\hline 36 & 12 & 1.69 & Human & Human \\
\hline 37 & 68 & 1.68 & Spam & Spam \\
\hline 38 & 14 & 1.67 & Spam & Human \\
\hline 39 & 79 & 1.57 & Spam & Spam \\
\hline 40 & 15 & 1.69 & Human & Human \\
\hline
\end{tabular}


klasifikasi k-Nearest Neighbour menunjukkan tingkat Hasil klasifikasi K-Nearest Neighbour dengan accurcy sebesar 80\%, precission 84\%, dan recall $84 \%$ parameter tweets similarity menggunakan smith pada klasifikasi $k=3$ dan 10 Fold Cross Validation. waterman dan waktru interval antar posting tweets Hasil yang didapatkan mempunyai selisih 5\% dengan menunjukkan tingkat accuracy deteksi bot spammer similarity yang menggunakan metode cosine simalirity, dan legitimate sebesar $80 \%$, precission $84 \%$, dan recall untuk penelitian selanjutnya bisa dikembangkan 84\%. Sedangkan penelitian sebelumnya yang dengan menambahkan jumlah dataset dan menggunaan cosine similarity dalam deteksi similarity menambahkan parameter lain dalam mendeteksi bot tweets menunjukkan tingkat accuracy 85\%, precission spammer seperti umur akun, jumlah pengikut, jumlah $94 \%$ dan recall $90 \%$

Tabel 2. Accuracy, Precission dan Recall

\begin{tabular}{|c|c|c|c|}
\hline \multicolumn{4}{|c|}{ Accuracy: $80.00 \%$} \\
\hline & True Spam & True Human & Precision \\
\hline Pred. Spam & 21 & 4 & $84.00 \%$ \\
\hline Pred. Human & 4 & 11 & $73.33 \%$ \\
\hline Recall & $84.00 \%$ & $73.33 \%$ & \\
\hline
\end{tabular}

\subsection{Grafik}

Dibawah ini merupakan grafik hasil prediksi deteksi bot spammer dengan menggunakan k-Nearest Neighbour dan Cross Validation, lihat Gambar 5.

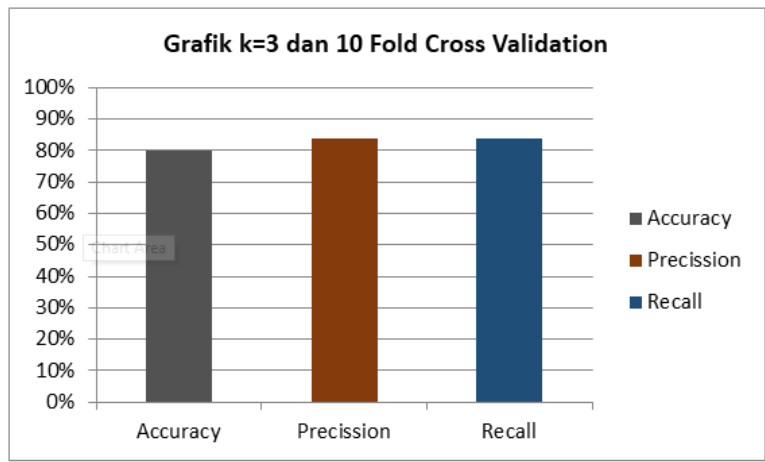

Gambar 5. Grafik Hasil Accuracy, Precission dan Recall

Gambar 5. menunjukkan tingkat accuracy terbaik dalam memprediksi akun bot spam dan legitimate sebesar $80 \%$, precission $84 \%$, dan recall $84 \%$.

\section{Kesimpulan}

\subsection{Simpulan}

Berdasarkan hasil penelitian yang telah dilakukan dengan memberdayakan ketersediaan pokok pemikiran, dokumentasi, dan alat bantu dapat disimpulkan hasil deteksi bot spammer dengan tweets similarity smith waterman menghasilkan nilai yang hampir mirip antara pengguna keduannya. Akun legitimate memiliki ratarata similarity kurang dari 28 kemiripan dan lebih dari sama dengan 1.68 pada interval waktu posting tweets. Sedangkan untuk akun bot spam memiliki rata-rata similarity lebih dari 28 kemiripan dan kurang dari 1.68 pada interval waktu posting. Sedangkan untuk prediksi Bot Spammer dan legitimate user menggunakan tweet dan retweet.

\subsection{Saran}

Suatu penelitian yang telah dilakukan merupakan awal dari penelitian selanjutnya. Tingkat hasil capain penelitian ini tentunya belum bisa dikatakan ideal untuk menjadi tolak ukur penelitian dengan pendekatan sejenis, namun dapat dijadikan sebagai dasar perbandingan untuk mendapatkan hasil yang lebih baik. Banyaknya alat bantu yang beragam dapat menarik peneliti untuk melakukan analisa dan perbandingan lebih mendalam agar menghasilkan sebuah kesimpulan tentang kesesuain alat bantu dengan kasus maupun skenario tertentu. Koleksi jumlah data yang lebih banyak perlu digunakan untuk meningkatkan akurasi dalam deteksi bot spam. Algoritma Smith Waterman yang digunakan untuk mendeteksi kesamaan dalam Tweets masih kurang cocok karena urutan huruf yang dihitung.

\section{Daftar Rujukan}

[1] W. Hidayat, "Kementrian Komunikasi dan Informatika Republik Indonesia," 2017. [Online]. Available: https://kominfo.go.id/content/detail/4286/pengguna-internetindonesia-nomor-enam-dunia/0/sorotan_media.

[2] D. P. Christian Sri Kusuma Aditya., Mamluatul Hani'ah., Alif Akbar Fitrawan., Agus Zainal Arifin., "Deteksi Bot Spammer pada Twitter Berbasis Sentiment Analysis dan Time Interval Entropy," J. Buana Inform., vol. 7, 2016.

[3] S. J. Zi Chu, Steven Gianvecchio, Haining Wang, "Who is Tweeting on Twitter: Human, Bot, or Cyborg?," in Proceedings of the 26th Annual Computer Security Applications Conference, 2010, pp. 21-30.

[4] H. L. Fred Morstatter., Liang Wu., Tahora H. Nazer., Kathleen M. Carley., "A New Approach to Bot Detection: Striking the Balance Between Precision and Recall," IEEE, 2016.

[5] Twitter, "Twitter," Twitter. .

[6] Hongyu Gao., Jun Hu., Christo Wilson., Zhichun Li., Yan Chen., Ben Y. Zhao., "Detecting and Characterizing Social Spam Campaigns," ACM, 2010.

[7] R. S. Perdana, T. H. Muliawati, and R. Alexandro, "Bot Spammer Detection in Twitter Using Tweet Similarity and Time Interval Entropy," J. Ilmu Komput. dan Inf., vol. 8, no. 1, p. 19, 2015.

[8] Mahdi Washha., Aziz Qaroush., Florence Sedes., "Leveraging Time for Spammers Detection on Twitter," ACM, 2016.

[9] Vincentius Riandaru Prasetyo., Edi Winarko., "Rating Of Indonesian Sinetron Based On Public Opinion In Twitter Using Cosine Similarity," IEEE, 2016.

[10] R. I. Abdul Munif., Rizky Januar Akbar., Ruchi Intan Tantra., "Rancang Bangun Sistem E-Learning Pemrograman Pada Modul Deteksi Plagiarisme Kode Program Dan Student Feedback System," J. Ilm. Teknol. Inf., vol. 15, 2017. 
Imam Safi'i, Arief Setyanto, Suwanto Raharjo

Jurnal RESTI (Rekayasa Sistem dan Teknologi Informasi) Vol . 2 No. 3 (2018) 633 - 638

[11] A. R. Radiant Victor Imbar., Adelia., Mewati Ayub., [13] Smith T.F., Waterman M.S., "Identification Of Common "Implementasi Cosine Similarity dan Algoritma SmithWaterman untuk Mendeteksi Kemiripan Teks," J. Inform., vol. Molecular Subsequencees," J. Mol. Biol, vol. 147, 1981. 10, 2015.

[12] Gotoh O, "An Improved Algorithm For Matching Biological Sequences," J. Mol. Biol, vol. 162, 1982. 